International Review of Research in Open and Distributed Learning Volume 21, Number 1

January - 2020

\title{
Getting Started with Open Badges and Open Microcredentials
}

Kyle Clements ${ }^{1}$, Richard E. West ${ }^{2}$, and Enoch Hunsaker ${ }^{3}$

${ }^{1}$ Western Governors University, ${ }^{2,3}$ Brigham Young University

\begin{abstract}
This article is intended as a practical resource to help interested organizations design and implement an open badging system. Open badges are a type of open credential designed to recognize a variety of skills, knowledge, and experiences, both inside and outside of traditional educational settings. While growing in popularity, common questions asked by those interested in using open badges include: How do I get started? What technologies exist to produce open badges? And what do I need to know? This article seeks to address questions such as these. First, we introduce the reader to key terms in the badging world and explore open badge design precedents, responding to who, what, how, where, and why open badges have been used in the past. Drawing on this research as well as our own personal experience, we then present a possible framework for getting started with open badges and a step-by-step guide for implementing that framework within your organization.
\end{abstract}

Keywords: open badges, alternative credentials, open credentials, microcredentials, open education 


\section{Getting Started With Open Badges}

It is undeniable that open education will play an important role in future education. The number of people seeking education is accelerating. This rush to education has increased due to the accessibility of the Internet, making it possible for potential learners in lower-income countries to access educational options. Open education is no longer simply a nice idea, but a necessity for providing affordable and accessible education to the world.

However, much of the focus in open education has been on open educational content and resources. Scholars study how to make reuse more common within content repositories (Santos-Hermosa, FerranFerrer, \& Abadal, 2017), and how to leverage the potential of MOOCs (Kopp, Gröblinger, \& Zimmerman, 2017). Most of the scholarship and discussion focuses on open textbooks, and their potential cost-savings (Wiley, Hilton, Ellington, \& Hall, 2012), their effect on pedagogy (Pitt, 2015), or their ability to increase access (Feldstein et al., 2012).

These positive impacts from open educational content are real and important. However, open educational content alone will not be sufficient to remedy to the world's educational challenges. Education is more than simply providing content, and includes effective assessment, formative and summative feedback, mentoring, authentic experiences for experiential and transformative learning, and creative/research opportunities. Wiley (2019) echoed this by arguing that open education requires open content, open competencies, open assessments, and open credentials.

As more students engage in learning from open content, providing the open credentials to recognize that learning will become increasingly crucial. However, the biggest question we get asked by educators interested in developing open credentials is how do I get started? This paper seeks to address this challenge by providing a review and synthesis of the work on open badges, a type of open microcredential.

\section{The Rise of Alternative Credentials}

In recent years, alternative credentialing has become an increasingly important method of recognizing learning and achievement that takes place in a wide variety of environments. Alternative credentials have been defined as "competencies, skills, and learning outcomes [that are] derived from assessment-based, non-degree activities and align to specific, timely needs in the workforce" (Fong, J anzow, \& Peck, 2016, p. 1). This rise in the popularity of alternative credentials is due, at least in part, to changes in the cost, availability, and perceived value of both formal (e.g., universities, colleges) and informal (e.g., MOOCs, YouTube, Khan Academy) learning opportunities; economic changes (e.g., rising tuition, dropping enrollment in institutions of higher education); and demographic shifts across the world (Fong et al., 2016).

One form of alternative credentialing that is rapidly gaining traction are open badges. Many corporations, government agencies, institutions of higher education, certification issuing organizations, and others are beginning to adopt open badges as a viable means to recognize learning, accomplishment, and other types of achievement (Devedžić \& Jovanović, 2015). An open badge is a digital microcredential that adheres to the open badge infrastructure (OBI) developed by the Mozilla Foundation and currently administered by IMS Global. OBI calls for badges to be formatted as images enriched with metadata (e.g., issuing organization, badge description, badge requirements, submitted evidence, standards, endorsements) that 
allow people to (a) digitally verify that the badge was earned by a particular recipient and (b) gain deep insight into the actual skills the badge earner possesses. Open badges are envisioned as (a) remixable (i.e., they can be mixed, matched, and republished to different audiences for distinct purposes); (b) controlled by the badge earner, rather than by an institution, in terms of how it is shared, collected, and displayed; (c) portable across media and thus widely shareable to anyone selected by the earner; and (d) issuable by any party, to any party, within any learning context (Mozilla Open Badges, 2014a). They also tend to be competency-based and to require evidence of completion in order to be earned (Jovanović \& Devedžić, 2014). While open badges are primarily a method for recognizing learning, they have been used for a wide variety of other purposes as well, including as (a) a mechanism for increasing learner motivation, (b) a means of charting learning routes or pathways, and (c) a strategy for supporting self-reflection, planning, and learner agency (Jovanović \& Devedžić, 2014).

A variety of tools have made it possible for organizations to begin issuing open badges with minimal effort required; however, many of those seeking to do so quickly find that implementing a successful badging program involves more than simply issuing badges. This article is intended as a practical resource to help interested organizations design and implement an open badging system. First, we introduce the reader to key terms in the badging world and explore open badge design precedents, responding to who, what, how, where, and why open badges have been used in the past. Drawing on this research as well as our own personal experience, we then present a possible framework (see Figure 1) for getting started with open badges and a step-by-step guide for implementing that framework within your organization.

\section{Key Badging Terms}

One of the disorienting issues for new organizations developing a badging system is the specific nomenclature used to describe persons and objects associated with badging. In brief summary, the process for open badges is to first create the badge image and its data (e.g., criteria, endorsements, and standards), and then upload this to a badge issuing platform. You can then issue badges to earners by entering their email. They can see, share, and store their badges in a digital backpack.

The following terms may be useful in understanding the remainder of this article as well as other literature surrounding open badges. These terms are frequently used by developers and the early adopters of open badges, and are often referenced in the open source code for open badging technologies.

- Assertion. Developer terminology for an earned badge. Assertions contain data unique to the recipient such as who earned the badge, who gave the badge, and what the badge represents (Mozilla Open Badges, 2014b).

- Backpack. An earner-controlled digital repository that facilitates the collection, categorization, and sharing of open badges.

- Badge Class. A description of what the badge represents, or what it means to receive one. This can include various pieces of data including who gives the badge, what the criteria is to earn one, 
when the badge might expire, what standards it is aligned to, and tags for organizing the badge classes (Mozilla Open Badges, 2014b).

- Competency-Based Education. According to the U.S. Department of Education (2019), competency-based education is learning that "allows students to progress as they demonstrate mastery of academic content, regardless of time, place, or pace of learning" (para. 1). Nodine (2016) described the history of competency-based learning as following centuries of traditional instruction that focused on mastery learning, such as through apprenticeships, craft guilds, and technical training programs. An early focus on learning outcomes also provided support for an emerging conceptualization of CBE as focused on what students learn, not how or where they learned it. This perspective contrasts with time-based perspectives on learning rooted in the Carnegie Unit, or credit hour, which since its introduction in 1906 has developed into a common standard for measuring time spent on learning and student readiness for higher education (Silva, White, \&Toch, 2015). However, many in higher education believe the Carnegie Unit is less useful in an information economy (Levine, 2015).

- Consumers/Interpreters. The ultimate audience of a badge - the individuals, employers, peers, and institutions, who use a badge to evaluate an individual's qualifications.

- Digital Badge. Badges that do not conform to the OBI standard. Often used in video games or to motivate student behavior but not portable between platforms.

- Earner. An individual who satisfactorily meets badge completion criteria and is awarded the badge by the issuer. "Badge earners can combine multiple OBs from different issuers, display them on the Web, and share them for employment, and/or further education" (Jovanović \& Devedžić, 2014, p. 116).

- Endorsements. A recent addition to the OBI that enables third parties to endorse an issuer's badge or an individual's earned badges. Endorsements are designed to bring greater value to badges as the recognition and value they receive from others is recorded in a badge's metadata.

- Evidence. Information embedded within the badge or linked out to separate web pages demonstrating what the recipient did to earn the achievement (IMS Global Learning Consortium, 2018).

- Issuer. The organization that designs and publishes a badge, reviews badge submissions, issues the badge to an earner, and provides digital verification of the badge's authenticity. "OBI defines the badge issuer as a learning provider or an employer awarding an OB for completing a certain task (tasks) and/ or attaining a certain goal (goals). The issuer creates the criteria that the badge earner needs to fulfill in order to win the badge" (Jovanović \& Devedžić, 2014, p. 116).

- Issuing Platform. A platform enables individuals and institutions to issue badges to their learners. In other words, if you want to give badges to your students, you create and upload your badges to an issuing platform, along with the criteria for earning the badge and a description of the 
badge. You can then usually send badges to students by email. Examples of badge issuing platforms include Badgr (https://badgr.io), Accredible (https://www.accredible.com); OpenBadges.me (https:// www.openbadges.me/openbadges); MyMantle (https://mymantl.com/); Open Badge Factory (https://openbadgefactory.com/), My Open Badge (https://myopenbadge.com), Badgewell (https:// www.badgewell.com), and Credly (https:// info.credly.com/). A complete list of certified (OBI 2.0 issuing platforms is available at https:// www.imsglobal.org/cc/statuschart/openbadges.

- Learning Pathways. Open badges can be organized into pathways by requiring badges as criteria for earning another badge, creating a guided path through the thousands of available badges for learners interested in a particular topic or trajectory. Emerging tools such as Badgr Pathways (https:// pathways.badgr.io) make it possible to create pathways utilizing open badges from various issuers.

- Metadata. Information embedded within a badge. Under the OBI standard, required metadata for a given badge includes a unique id, recipient information, issuer information, badge name, description, criteria, image and date issued. Optional metadata includes evidence, a narrative explaining evidence, expiration date, educational standards the badge aligns to, tags describing the achievement, and whether or not the badge has been revoked (IMS Global Learning Consortium, 2018).

- Microcredential. A credential recognizing a distinct skill or accomplishment. Microcredentials come in a variety of formats including certificates, nanodegrees, digital badges, and open badges.

- Open Badge Infrastructure (OBI). Open Badge Infrastructure-the technical standard for open badges developed by the Mozilla Foundation and maintained by IMS Global. The OBI facilitates the portability and interoperability of the badging system; "OBI comes with a set of open application programming interfaces (APIs) that allow developers to integrate OB services with existing applications, Websites, and social networks." (Jovanović \& Devedžić, 2014, p. 116).

- Verification. A process by which the validity of a badge can be confirmed. Most OB issuing tools provide instructions for verifying badges issued by their system.

\section{Badging Precedents}

Open Badges have been issued in a variety of settings: universities, massive open online courses (MOOCs), K-12 schools, and informal learning groups (Abramovich, Schunn \&Higashi, 2013; Ahn, Pellicone, \&Butler, 2014; Cross \& Galley, 2012; McDaniel, Lindgren \& Friskics, 2012). Open Badges have been used in these settings for several purposes including as a tool to motivate learners and incentivize learners (Aberdour, 2016; Gibson, Ostashewski, Flintoff, Grant, \& Knight, 2015; Jovanović \& Devedžić, 2014; Santos et al., 2013). They have also been used to guide learning, increase engagement, and promote specific brands (Jovanović \& Devedžić, 2015; Leaser, 2018). Also, of course, they have been used to certify or recognize 
skills and learning (Aberdour, 2016; Jovanović \&Devedžić, 2014; Gibson et al., 2015; Young, West, \&Nylin, 2019), especially recognition for skills learned outside formal schooling.

What can open badges be used for? Almost anything, it seems, related to informal or formal learning, activity, and skill. As this can be a little overwhelming for anyone getting started with open badges, we provide the following examples so others can learn from the experience of these initiatives.

\section{Who Is Issuing Open Badges and To Whom?}

There have been over 1,400 institutions who had issued open badges as of 2013 (Mozilla Open Badges, 2018). As the list below indicates, open badges are currently being issued by a wide variety of organizations to an even wider variety of target audiences. Higher education institutions are issuing badges to their students (Gibson, Coleman, \& Irving, 2016; Randall, Harrison, \& West, 2013), K-12 schools and districts are issuing badges to teachers for professional development (Davis, 2017; Gamrat, Zimmerman, Dudek, \& Peck, 2014; Lynch, 2018; Otter, 2018), teachers, tutors, and coaches are issuing badges to their individual students (e.g., Aurora Public Schools, 2017; Corona-Norco Unified School District, 2018; Davis, 2017; Lynch, 2018; Otter, 2018), and sometimes, badges can be for extracurricular learning, such as with afterschool programming (Davis \& Singh, 2015).

The beauty of flexible and open credentials such as open badges is that they can also be issued by nontraditional learning institutions or experience providers. For example, corporations (e.g., IBM; see https:/ / www.youracclaim.com/ organizations/ibm/ badges) are issuing badges to employees and members of the community, including customers (Young et al., 2019). Libraries and museums are issuing badges to their patrons, in particular to youth as part of their summer learning programs (Chicago City of Learning, 2017). Professional development organizations and credentialing bodies are issuing badges to trainees.

This flexibility provides the opportunity for open badges, and other open credentials, to address the challenge of access in education, by enabling other providers/ supporters of learning outside of traditional universities to provide their own recognition of the skills and knowledge earners achieve. As an example, nonprofits issue badges to assist employability of patrons (e.g., Badges for Vets, focused on translating military-learned skills to civilians). Examples include Newport City Homes (Ifenthaler, Bellin-Mularski, \& Mah, 2016), which provides trainees hands on construction skills, and National Health Service (Alexander \&Neill, 2018) in the UK, which uses badges to promote children's education of health and wellness.

Institutions seeking to set up their own badging system may benefit from reviewing the cited resources for organizations similar to their own. These articles cited are examples only, as there are too many cases to list for each one.

\section{What Badges are They Issuing?}

Badges can be issued for learning or achievement within any subject domain. They can also follow any classification or leveling system that meets the needs of the issuer and earners. Some general ideas for badges within a system include color coding the badges; using levels (e.g., bronze/ silver/ gold or Level 1/2/3); attaching categories or tags; and using meaningful icons (Santos et al., 2013). In considering how 
to establish their own badging systems, organizations may find it useful to consult some of the following precedents.

Skill badges. IBM issues badges focusing on professional technical skills. Their badges are organized into categories such as analytics, cloud, mobile, and security. Similarly, Brigham Young University (BYU), Purdue, and The University of Memphis issue badges focused on various technology skills for educators. There is little hierarchy among the badges, but each badge is tagged with specific categories, such as media production or assessment tools. Another example is that of Colorado Community College System responding to address a perceived skills gap between graduates and employers by using badges to better communicate the skills of potential employees.

Knowledge badges. Many, if not most, badging organizations offer some badges for acquiring knowledge, sometimes in preparation for applying that knowledge in skills-based badges. One example is the extensive badging program offered by Wichita State University, which includes badges for skills and completing projects, but many for acquiring knowledge in disciplines such as health care, library sciences, business, and engineering ( see http:// badges.wichita.edu/ badgecatalog).

Social or life skills. Many organizations are exploring using badges to recognize learners' efforts to develop social and life skills that are not typically taught in classes, but are important for a successful life. The University of Central Oklahoma has created a Student Transformative Learning Record that encourages and recognizes, through open badges, students gaining abilities in global and cultural competencies, health and wellness, leadership, service learning and civic engagement, disciplinary knowledge, and research and creative activities (see http://sites.uco.edu/central/tl/stlr/). Similarly, the Education Design Lab has created badges for 21st century learning (see https:// eddesignlab.org/ badgingchallenge/) that includes skills in cultural fluency, creativity, empathy, and resilience.

Participation badges. Siemens (a multinational industrial manufacturing company) issues a variety of badges, including a voluntary participation badge for those who volunteer to contribute to a Siemens project for one day (see https://www.openbadgeacademy.com/badge/ 1273). Cambridge University Press offered badges for participating in Cambridge Day events and workshops (https:// www.cambridgeenglish.org/it/ events/openbadges/).

Identity badges. Earning a badge can represent a person's entry into and development as a member of a community. In this way, badges can help one develop an identity as a professional in a certain discipline or community, which can be particularly valuable for students who may otherwise feel disenfranchised. When an organization certifies that someone belongs, or has successfully started on a path to becoming a full member of the community, such badges contribute to sense of belonging and identity development. The University of New Mexico's Chemical and Biological Engineering program has experimented with such badges as part of furthering students' sense of identity as engineering professionals. They found that in first year courses, the students most interested in earning professional engineering identity badges were non-traditionally-aged students (Svihla, personal communication, September 26, 2019). 
Earning a badge can represent development of a person's expertise and their evolution into becoming key members of a community. In this way they can help one develop an identity as a professional in a certain discipline or community, which can be particularly valuable for traditionally disenfranchised or minority persons. The University of New Mexico's chemical engineering program offers badges to students to provide flexible and responsive learning opportunities as part of furthering students' sense of identity as engineering professionals.

Certification badges. Badges can be used as certificates that represent culminating achievements in a portable, data-rich way. Davies, Randall, and West (2015) outlined how badges could help certify professional evaluators. Microsoft, Apple, and National Instruments are some companies using open badges to issue certificates.

\section{Where Are They Issuing Badges?}

Open badges have been used in all educational settings, including corporate, K-12, higher education, informal and formal learning experiences. They are particularly useful in distributed learning environments, as the open badge can be issued and then shared via the Internet. With many encouraging movement towards an open recognition ecosystem, the potential is to make recognizing learning and skill something everyone can eventually give to others, not just seek for themselves (see https:// www.openrecognition.org/).

\section{Creating a Badging Program}

The remainder of this article provides a framework for approaching the design of a badging program. We have divided this process into four phases: (1) Design the system, (2) Design the badges, (3) Publish, and (4) Emphasize change management. Figure 1 provides a visualization of these stages and subcomponents. Although we represent these stages linearly, the context of a given program may lead to dependencies between stages and their subcomponents. Flexibility should be allowed in the design process by anyone seeking to follow these guidelines. 


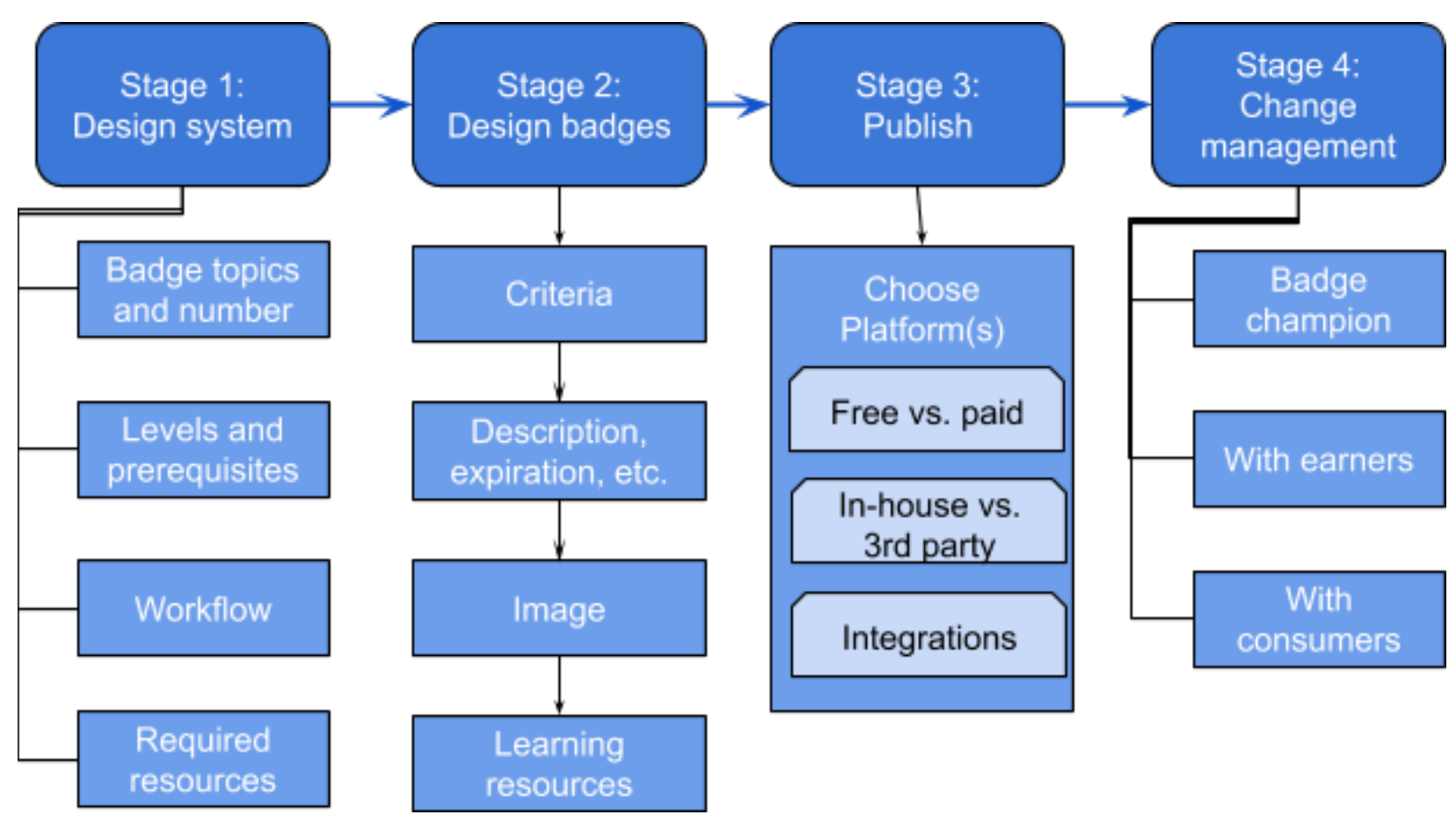

Figure 1. Suggested design process for designing open badging systems.

\section{Stage 1: Design the System}

The complexity of a badging program grows as the number of badges and earners increases. For this reason, planning the broader system in which individual badges and earners will take part in is essential. This includes, considering the number of topics a program will include, the amount of badges aligned with each topic, and the resources available to implement the design.

Program scope. One challenge every badging initiative faces is determining what competencies will be represented. A common pitfall many badging initiatives fall into is the temptation to badge everything. Our recommendation, despite planning the broader system for eventual growth, is that badging programs start small by focusing on a few core skills.

Workflow. The process by which participants in the program find and earn badges will have implications for how badges will be formatted and which badging platform should be used. Does the evaluation process need to be integrated into an existing workflow? How will earners know what badges are available? What will the interaction between earners and evaluators be like? Answering questions such as these can help guide the decision-making process later on. It may be helpful to consider broadly what type of system metaphor you are seeking. Do you want a system where learners browse badges and apply for them, one where issuers award badges based on evidence acquired outside of the system (perhaps as part of a course management system), one where badges can be earned as part of gamification, or something else?

Identify participants. Badging initiatives often begin with a specific population of earners in mind. Those designing the program should consider how this population may change over time and how those changes may impact the structure of the program. For example, it may be useful to design the badges 
to allow for future levels, as badge earners may want to continue their professional learning. Equally important is considering how those playing an administrative role in the badging program may change over time, and how the administration of the badging system can be continued during this transition.

Resources. Beyond personnel, what resources are available to implement the badging program? One example may be funds required for updating the badges if they get outdated or paying for someone to review and award the badges. Will these resources be available on an ongoing basis? Will those evaluating badge criteria require training of any kind? How will badge evidence be hosted online? Each of these decisions will have implications for the amount of resources required to sustain the badging program. For example, requiring expert human grading of evidence can provide higher rigor, but also a higher cost. Perhaps it is useful to explore peer evaluation and other methods of crowdsourcing the "expense" of badge reviewing.

\section{Stage 2: Design the Badges}

Since the image representing an open badge is its most visible component, designing an open badge involves much more than creating a simple graphic. Designers will need to determine the scope of what the badge represents, specify metadata values, and plan for how learners will complete the badge's requirements.

Badge scope. Open badges can represent any number of skills or experiences; however, most badges are designed to represent distinct individual skills or accomplishments. In such settings, tiered systems with multiple badges (i.e., beginner, intermediate, expert) can be used to represent complicated skills.
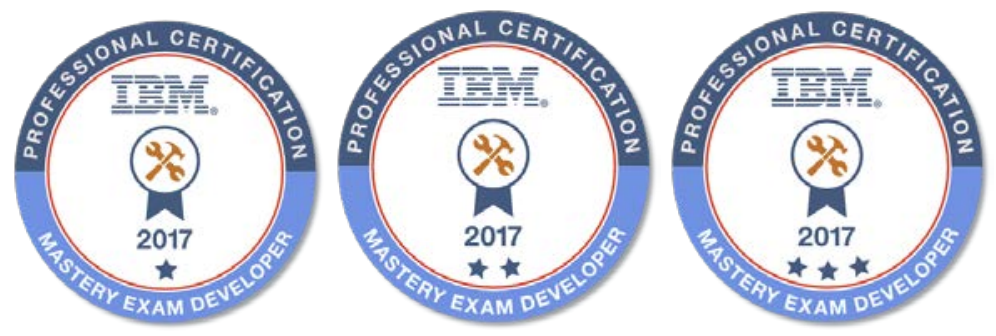

Figure 2. Tiered badging system. IBM uses stars to indicate the level of skill a particular badge represents.

Metadata. Every open badge is embedded with metadata including the badge name, description, criteria, issuer information, evidence, date issued, and other fields. Most badge issuing tools guide theissuer through the badge creation process and will indicate which fields of data need to be completed. Adding as much metadata as possible helps to increase the perceived rigor of each badge and its value to badge earners and consumers. 


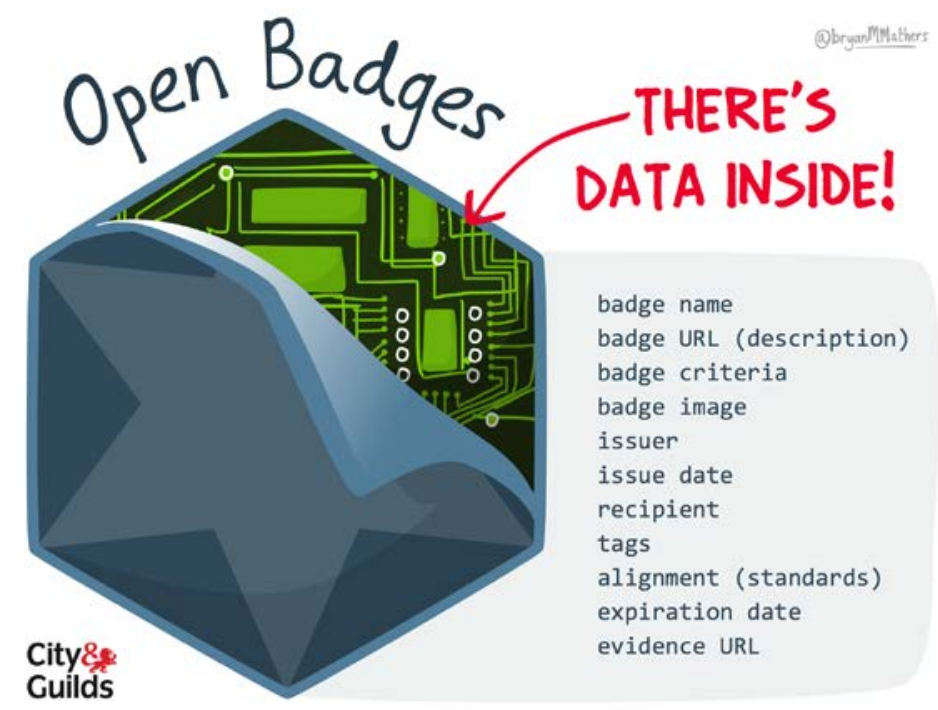

Figure 3. A visual representation of the kinds of data that can be included in an open badge. Adapted from “Open badges (P.S. there's data inside...)," by Mathers, 2019 (https:// bryanmmathers.com/ open-badgesdata-inside//). Image is licensed CC-BY-ND.

Badge images. Although metadata often explains the significance of a given badge, the badge image is what gives the first impression. One study found the credibility of an entire program can belowered by less aesthetically pleasing badge images (Dyjur \& Lindstrom, 2017).

The images themselves can be created using any tool and then uploaded to the issuing platform. Some platforms even allow the user to generate potential images while creating the badge. Alternatively, tools such as Makebadges (http:// www.makebadg.es/ badge\#) allow users to create badge images and download them.

Learning resources. Open badges are often connected to broader competency-based learning programs (Hickey, Willis, \& Quick, 2015). Badges are usually designed to include in the metadata an explanation of the criteria or competencies earners are required to complete, but they do not include instructions on how to achieve that competency (i.e., they display the task you need to do, but lack the training on how to do it). For this reason, we recommend that a badging program provide guides or references outside the badge metadata to guide potential earners in obtaining the necessary skills. This can be a website or a learning management system that accompanies and supports the badges.

Managing a team. Many badging systems rely on a team to create and manage the badges. Scaffolding team members with clear templates can help keep all badges uniform. In one study, Randall, West, \& Farmer, in press) found that by emphasizing effective training of undergraduate badge designers enabled thesenewer designers to create badge rubrics and designs that were as high quality as those created by more experienced professionals. The key, it seems, is in the training, templates, documentation, and opportunities for peer review (see Figures 4-5 for examples of some scaffolding documents we used in developing our educational technology badges). 


\section{Badgeschool Design and Publishing Processes}

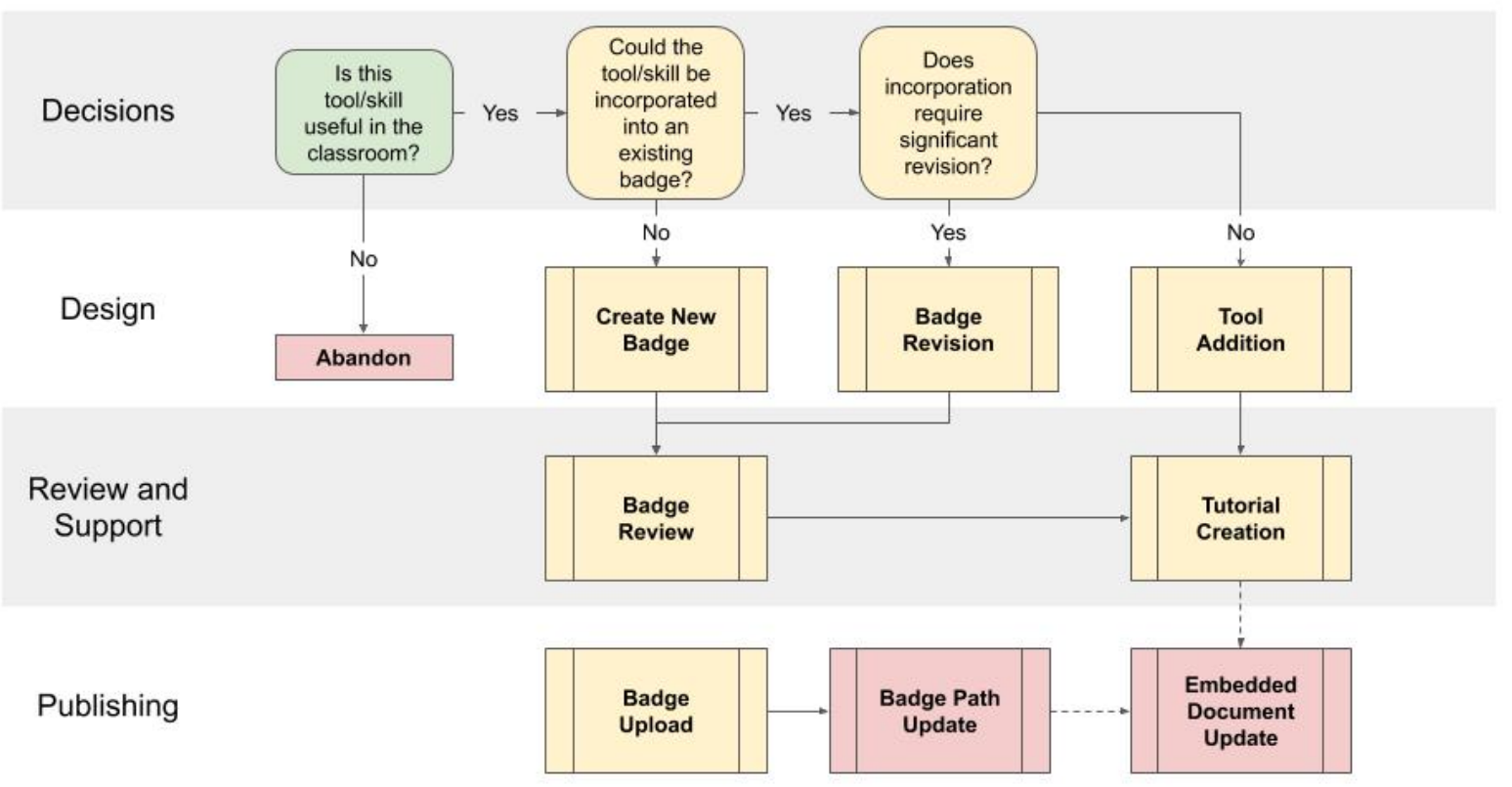

Figure 4. One of many internal Google documents used to scaffold new badge designers. Badge designers were typically teaching assistants in the courses, who had strong content area experience but limited badge design experience, and who were rotated frequently (see Randall,Farmer, \&West, 2019).
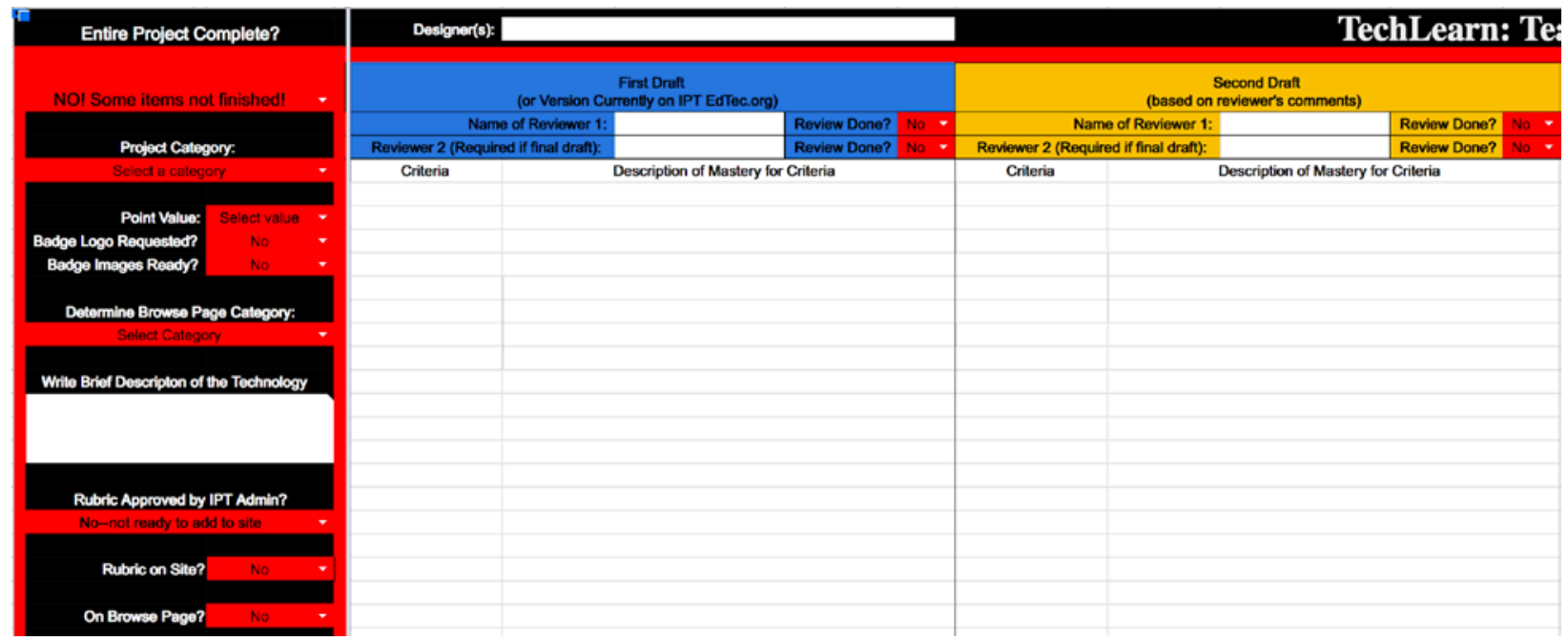

Figure 5. An example of one of the Google Sheets rubrics used to scaffold new badge designers. This scaffolding was done through the process of drafting and revising a new educational technology badge, and making certain all new badges were reviewed and approved. We found it to be much more efficient to do the bulk of the badge design work in Google Docs and Sheets before transitioning to the badging platform.

\section{Stage 3: Publish}

The third stage of creating a badge program includes publishing the badges with your selected badge issuing tool and making them available to earners. A variety of platforms exist for this purpose; the complete list of 
issuing platforms that are fully compliant with the OBI 2.0 specification is available here: https:// www.imsglobal.org/ cc/ statuschart/ openbadges.

Choosing a platform. Every open badge issuing platform is unique. We recommend reviewing multiple platforms before decided which one will be used to implement your program. Where possible, creating one or two badges within each platform can give you a sense of how your program would work using that tool. Consider the following issues as you make your selection.

Workflow. If possible, create a badge using the platform you are considering. Walk through the process of earning the badge to make sure the platform supports the types of interactions you envision for the program. Also consider whether or not the platform you are considering can integrate with tools already being used by your organization, such as learning management systems.

Permissions. Several badging platforms offer varying levels of permissions that enable members of the badging organization to fulfill different roles. For example, one account may be allowed to edit and add badges while another can only issue them.

Cost. Specific features may only be available for on a subscription basis. Other platforms provide their features for free up to a certain number of badges or users. Consider what the potential of your program is to grow and whether or not the potential of added costs may limit that growth.

\section{Stage 4: Emphasize Change Management}

Every organization will likely require a cultural shift of some kind when implementing a badging program. The following recommendations may assist in ensuring a smooth transition to badging.

Find a Badge champion. As outlined here, implementing a successful badging program requires several steps. For this reason, we recommend designating someone within the organization to lead out on designing and implementing the program. This allows for the creation of badges, selection of an issuing tool, and other essential decisions to be coordinated and helps ensure none of these steps are forgotten.

Focus on earners. A warm reception to the badging program by those who are expected to participate in earning badges greatly enhances the transition. We have found including earners in the badge design process, starting small and iterating based on earner feedback, and where applicable allowing earners to apply for badges based on their prior work and experience, can improve reception of a program. In addition, clear training ahead of time about what badges are, and why they can be valuable, can quickly answer many of the common questions and encourage greater badge earning participation.

Focus on consumers. Most badging programs hope to increase the acceptance of badges among badge consumers (those who will see the badges and value them). Several forms of microcredentials have begun to emerge, however employers have been slow to adopt these alternatives (Fong et al., p. 15). The best thing a program can do to ensure a positive reception by badge consumers is work with badge consumers to design the program in the first place. While this may not be feasible for a widespread audience, incorporating a consumer's input early on will help them value the completed program. For 
example, in designing our preservice educational technology badges, we responded to feedback from the local school districts and national educational technology associations about how to improve the badges.

An open badge's metadata provides another opportunity to improve consumer reception. When designing a badge, consider how well the description and criteria will be understood by an external audience. Providing a brief description of the review process and anticipated amount of work required to earn the badge can go a long way towards helping someone else understand what the badge represents.

\section{Conclusion}

The goal of this paper was to answer the question many have asked about open badging, "how do I get started?" Because open badging was originally a technological innovation, technical jargon surrounding the technology has sometimes been a hurdle to teachers or institutions wanting to become badge issuers. In addition, a microcertificate, skill-based paradigm, is very different from many educational systems, and adopting open badging can require significant systemic change, leading to additional concerns and questions. This article, we hope, addresses some of the most common of these questions and can help open up the world of microcredentialing to more teachers.

While we have seen many benefits from open badges, open badging and alternative credentials are not a panacea for solving educational problems (are any educational technologies?). Many misunderstand this, and can be frustrated when open badges do not solve problems such as how to ascertain if someone has developed a soft skill (e.g., leadership, motivation, collaboration) or questions such as how to know if someone really has earned a badge and developed the skill. These are assessment problems already existing in education, no matter the credential received at the end. In addition, some have concerns about how to know what skills are worth receiving a badge for-in other words, what learning and development is most important? This, again, is not really a badging problem as much as a learning objectives problem.

In this and other situations, we have seen that engaging in open badging has caused us to reflect more deeply about what our goals are for a particular learning situation, what we feel matters, what we want people to know and be able to do, and how we think we will know when they have done it. These are important questions, which can lead to significant pedagogical reform, which has been our experience. Because of this, one of the greatest benefits of alternative credentials, such as open badges, is they are the catalyst to force us to think about alternative educational practices and processes.

In addition, the emphasis that open badging gives to micro certification, rather than larger scale certificates such as degrees and diplomas, can open up possibilities for a re-organizing of learning systems, where learning can happen from one institution or many, at one time or over time, and in this way perhaps break free from the tyranny of the one semester, " $X$ " credit hour system that artificially constrains many learning experiences. In this way, open badges and microcredentials may be the key to unlocking the potential of MOOCs, online modules, and open courseware by providing a credentialing option for these open resources. In addition, open badges could provide the opportunity to break down barriers between informal and formal learning, and professional education and academic education. 
It is unknown what the future of open badging may be, or whether it may be supplanted by future technologies. However, these pedagogical and philosophical questions about what we feel the nature of education is and should be will remain. Whatever the future of education, we feel confident it will involve increased opportunities for some kind of skill-based, micro learning in addition to other educational practices. As open education evolves, we believe the field will need to build off of the success it has had in creating open content, and address how to provide learning that is more skills-based, distributed, flexible, and linked to $21^{\text {st }}$ century career needs. Open badges will not give us all the answers, but we do feel that open credentials can provide at least the technological opportunity to explore possibilities. 


\section{References}

Aberdour, M. (2016). Transforming workplace learning culture with digital badges. In D. Ifenthaler, N. Bellin-Mularski, \& D.-K. Mah (Eds.), Foundation of digital badges and micro-credentials: Demonstrating and recognizing knowledge and competences (pp. 203-219). Cham, Switzerland: Springer International Publishing.

Abramovich, S., Schunn, C., \& Higashi, R. M. (2013). Are badges useful in education? It depends upon the type of badge and expertise of learner. Educational Technology Research and Development, 61, 217-232. https:// doi.org/ 10.1007/s11423-013-9289-2

Ahn, J ., Pellicone, A., \& Butler, B. S. (2014). Open badges for education: What are the implications at the intersection of open systems and badging? Research in Learning Technology, 22, p. 1-13. https:// doi.org/ 10.3402/ rlt.v22.23563

Alexander, J . H., \&Neill, S. (2018). The psychosocial impact of NHS digital badges on a school-aged cohort. J ournal of Child Health Care, 22(4), 619-630.

https:// doi.org/ 10.1177/ 1367493518767777

Aurora Public Schools. (2017). Digital badges in APS: What types of badges can students earn? Retrieved from https:/ / aurorak12.org/ 2017/03/20/ digital-badges-in-aps-what-types-of-badges-canstudents-earn/

Chicago City of Learning. (2017). What is Chicago city of learning? Retrieved from https:// chicagocityoflearning.org/about

Corona-Norco Unified School District. (2018). Passport to success. Retrieved from https:// www.cnusd.k12.ca.us/our_departments/educational_services/curriculum instruction /passport to_success

Cross, S., \& Galley, R. (2012, November 16). MOOC badging and the learning arc (Blog post). OLDS MOOC. Retrieved from http:// oro.open.ac.uk/42038/

Davies, R., Randall, D., \&West, R. E. (2015). Using open badges to certify practicing evaluators. American Journal of Evaluation, 36(2), 151-163. https:// doi.org/ 10.1177/ 1098214014565505

Davis, K., \& Singh, S. (2015). Digital badges in afterschool learning: Documenting the perspectives and experiences of students and educators. Computers \& Education, 88, 72-83. https:// doi.org/ 10.1016/j.compedu.2015.04.011

Davis, M. R. (2017, September 27). Rewarding fine-tuned skills. Education Week, 37(6), 19-20. Retrieved from http:// ew.edweek.org/nxtbooks/ epe/ ew_09272017/ index.php?startid=19\#/ 20

Devedžić, V., \& Jovanović, J. (2015). Developing open badges: A comprehensive approach. Educational Technology Research and Development, 63, 603-620. https:// doi.org/ 10.1007/ s11423-015- 
$\underline{9388-3}$

Dyjur, P., \& Lindstrom, G. (2017). Perceptions and uses of digital badges for professional learning development in higher education. TechTrends, 61(4), 386-392. https:// doi.org/ 10.1007/s11528$\underline{017-0168-2}$

Feldstein, A., Martin, M., Hudson, A., Warren, K., Hilton III, J ., \&Wiley, D. (2012). Open textbooks and increased student access and outcomes. European J ournal of Open, Distance and ELearning, 15(2). Retrieved from https:// www.eurodl.org/materials/contrib/2012/Feldsteint_et_al.pdf

Fong, J ., J anzow, P., \& Peck, K. (2016, J une). Demographic shifts in educational demand and the rise of alternative credentials. Pearson. Retrieved from http:// upcea.edu/wpcontent/uploads/2017/ 05/ Demographic-Shifts-in-Educational-Demand-and-the-Rise-ofAlternative-Credentials.pdf

Gibson, D., Coleman, K., \& Irving, L. (2016). Learning journeys in higher education: Designing digital pathways badges for learning, motivation and assessment. In D. Ifenthaler, N. Bellin-Mularski, \& D.-K. Mah (Eds.), Foundation of digital badges and micro-credentials (pp. 115-138). Cham, Switzerland: Springer International Publishing.

Gibson, D., Ostashewski, N., Flintoff, K., Grant, S., \& Knight, E. (2015). Digital badges in education. Education and Information Technologies, 20, 403-410. https:// doi.org/ 10.1007/ s10639-013$\underline{9291-7}$

Hickey, D. T., Willis, J ., \& Quick, J . (2015). Where badges work better. Educause learning initiative (ELI Brief). Educause Learning Initiative. Retrieved from https:// library.educause.edu/resources/2015/6/ where-badges-work-better

Ifenthaler, D., Bellin-Mularski, N., \& Mah, D. K. (2016). Foundation of digital badges and microcredentials. Cham, Switzerland: Springer International Publishing.

IMS Global Learning Consortium. (2018). Open Badges v2.0 IMS final release. IMS Global Learning Consortium. Retrieved from https:// www.imsglobal.org/sites/default/files/Badges/OBv2p0Final/index.html\#BadgeObjects

Jovanović, J ., \& Devedžić, V. (2014). Open badges: Novel means to motivate, scaffold and recognize learning. Technology, Knowledge and Learning, 20, 115-122. https:// doi.org/ 10.1007/ s10758$\underline{014-9232-6}$

Kopp, M., Gröblinger, O., \&Zimmermann, C. (2017, May). Increasing educational value: The transformation of MOOCs into open educational resources. In European Conference on Massive Open Online Courses (pp. 223-232). Cham, Switzerland: Springer International Publishing. 
Leaser, D. (2018, August 6). Open badges: A better way to track skills and accomplishments (Blog post). IBM. Available at https:/ / www.ibm.com/blogs/ibm-training/ open-badges-a-better-way-to-trackskills-and-accomplishments/

Levine, A. (2015, October 8). Let's bid farewell to the Carnegie unit (Blog post). Inside Higher Ed. Retrieved from https:// www.insidehighered.com/ views/2015/ 10/ 08/waning-carnegie-unit-essay

Lynch, M. (2018, March 18). 5 ways to use digital badges in the classroom (Blog post). The Tech Edvocate. Retrieved from https:// www.thetechedvocate.org/5-ways-to-use-digital-badges-in-theclassroom/

Mathers, B. M. (2019, November 13). Open badges (P.S. there's data inside ...). Retrieved from https:// bryanmmathers.com/ open-badges-data-inside

McDaniel, R., Lindgren, R., \& Friskics, J . (2012, October). Using badges for shaping interactions in online learning environments. In 2012 IEEE International Professional Communication Conference (IPCC; pp. 1-4). https:// doi.org/ 10.1109/ IPCC.2012.6408619

Mozilla Open Badges. (2014a, October 29). Badges/ Onboarding-issuer. Retrieved J uly 23, 2018, from https:// wiki.mozilla.org/Badges/Onboarding-Issuer

Mozilla Open Badges. (2014b, September 29). Assertion information for the uninitiated. Retrieved from https:// github.com/ mozilla/ openbadges-backpack/ wiki/ assertion-information-for-theuninitiated

Mozilla Open Badges. (2018, J anuary 31). In Wikipedia. Retrieved J anuary 31, 2018, from https:// en.wikipedia.org/wiki/Mozilla_Open_Badges

Nodine, T. R. (2016). How did we get here? A brief history of competency-based higher education in the United States. The J ournal of Competency-Based Education, 1, 5-11. https:// doi.org/ 10.1002/ cbe2.1004

Otter, M. (2018, J uly 23). 6 things you need to know about digital badges. eSchool News. Retrieved from https:// www.eschoolnews.com/ 2018/ 07/23/ 6-things-you-need-to-know-about-digital-badges/

Pitt, R. (2015). Mainstreaming open textbooks: Educator perspectives on the impact of openstax college open textbooks. The International Review of Research in Open and Distributed Learning, 16(4), 133-155. https:// doi.org/10.19173/irrodl.v16i4.2381

Randall, D. L., Harrison, J . B., \&West, R. E. (2013). Giving credit where credit is due: Designing open badges for a technology integration course. TechTrends, 57(6), 88-95. https:// doi.org/ 10.1007/ s11528-013-0706-5

Randall, D., West, R. E., \& Farmer, T. (2019). Effectiveness of undergraduate instructional design assistants in scaling a teacher education open badge system. Contemporary Issues in Technology 
and Teacher Education, 19(4). Retrieved from https:// www.citejournal.org/volume-19/issue-419/general/ effectiveness-of-undergraduate-instructional-design-assistants-in-scaling-a-teachereducation-open-badge-system

Santos, J . L., Charleer, S., Parra, G., Klerkx, J ., Duval, E., \& Verbert, K. (2013). Evaluating the use of open badges in an open learning environment. In Scaling up learning for sustained impact (pp. 314327). Heidelberg, Berlin: Springer. https:// doi.org/10.1007/978-3-642-40814-4_25

Santos-Hermosa, G., Ferran-Ferrer, N., \&Abadal, E. (2017). Repositories of open educational resources: an assessment of reuse and educational aspects. The International Review of Research in Open and Distributed Learning, 18(5), 84-120. https:// doi.org/ 10.19173/irrodl.v18i5.3063

Silva, E., White, T., \& Toch, T. (2015). The Carnegie unit: A century-old standard in a changing education landscape. California: Carnegie Foundation for the Advancement of Teaching. Retrieved from http:// files.eric.ed.gov/ fulltext/ED554803.pdf

U.S. Department of Education. (2019). Competency-based learning or personalized learning. Retrieved from https:// www.ed.gov/ oii-news/ competency-based-learning-or-personalized-learning

Wiley, D. (2019). Open Educational Resources. In R. E. West, Foundations of Learning and Instructional Design Technology: The Past, Present, and Future of Learning and Instructional Design Technology. EdTech Books. Retrieved from https:// edtechbooks.org/lidtfoundations/open_educational_resources

Wiley, D., Hilton III, J . L., Ellington, S., \& Hall, T. (2012). A preliminary examination of the cost savings and learning impacts of using open textbooks in middle and high school science classes. The International Review of Research in Open and Distributed Learning, 13(3), 262-276. https:// doi.org/ 10.19173/irrodl.v13i3.1153

Young, D., West, R. E., \& Nylin, T. A. (in press). Value of open badge microcredentials to employees, customers, and the organization: A case study. International Review of Research in Open and Distributed Learning, 20(5).

\section{Athabasca University}

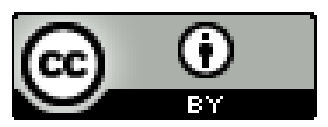

